\title{
Taxpayer Compliance in SME's Sector: A Theory of Planned Behavior
}

\section{HeniSuryanti}

\{suryanti_heni@yahoo.co.id\}, Universitas Nasional, Jakarta, Indonesia.

\section{Gagaring Pagalung}

\{gpagalung@gmail.com\}, Faculty of Economics and Business,Hasanuddin University, Makassar, Indonesia.

\section{Haliah}

\{haliah3107@gmail.com\}, Faculty of Economics and Business,Hasanuddin University, Makassar, Indonesia.

\section{Hamid Habbe}

\{hamidhabbe@gmail.com\}, Faculty of Economics and Business, Hasanuddin University, Makassar, Indonesia.

\begin{abstract}
This study aims to identify compliance with paying taxes using the Theory of Planned Behaviour (TPB).The variables used in this study are the attitude, Subjective norms and behavioural control to measure tax compliance, taxpayer with the subject of research at the Department of Cooperatives and SME's in the City of Depok, West Java. This research used primary data directly from the first party by distributing questionnaires directly to the SME's taxpayer. Data processing used SPSS version 25.0. The results of this research result the data that attitudes, norms and behavioural control Subjective Affect taxpayer compliance. Attitudes and behavioural control have a positive and significant to tax compliance while for subjective norms had a negative andsignificantto tax compliance. This shows that Taxpayers of Depok SME's pay taxes on their own awareness rather than the influence of opinions or suggestions from others.
\end{abstract}

Keywords:

Compliance paying taxes, theory of planned behaviour

Article Received: 18 October 2020, Revised: 3 November 2020, Accepted: 24 December 2020

\section{Introduction}

Tax has a very significant role in the state, main for development implementation. Taxes are a source of state revenue to finance all expenses including development expenses. Development is a government activity that takes place continuously and continuously which aims to improve the welfare of the community.
The funds listed in the State Revenue and Expenditure Budget (APBN) constitutes the Reviews largest domestic revenues. Every year the government always Strives to Increase tax revenues to finance state expenditures and development the following is the realization of state revenues for three years from 2017 and 2018.

Table 1. Realization of State Revenue (Billion Rupiahs) 2017-2018

\begin{tabular}{ccc}
\hline Source Acceptance & $\mathbf{2 0 1 7}$ & $\mathbf{2 0 1 8}$ \\
\hline I. Acceptance of the Interior & $1,654,746.10$ & $1,897,643.40$ \\
Tax Revenues & $1,343,529.80$ & $1,548,485.00$ \\
Domestic Tax & $1,304,316.30$ & $1,506,436.20$ \\
Income tax & $637,859.30$ & $761,200.30$ \\
value-added tax & $480,724.60$ & $564,682.40$
\end{tabular}


property tax

16770.30

Tax on Acquisition of Land and

Building

Excise

Other tax

Tax International Trade

Import duty

Export tax

Non Tax Receipts

Acceptance SDA

Profit SOE

Non Tax Receipts others

Revenue Public Service Agency

II. GRANT
0

$153,288.10$

15672.60

39213.60

35066.20

4147.40

$311,216.30$

$111,132.00$

43904.20

$108,834.60$

47345.50

11629.80

$1,666,375.90$
17433.90

0

$155,504.80$

7614.90

42048.80

37600.40

4448.40

$349,158.30$

$169,196.30$

44695.40

91962.10

43304.60

5383.20

$1,903,026.60$

Source: www.bps.go.id

AMOUNT

Income Tax is one of the taxes that have a substantial amount of income, including the SME's tax, along with the number of SMEs:

Table 2. Number of MSMEs

\begin{tabular}{|c|c|c|c|c|c|c|}
\hline \multirow[b]{2}{*}{ No. } & \multirow[b]{2}{*}{ Indicator } & \multirow[b]{2}{*}{ Unit } & \multicolumn{2}{|c|}{2016} & \multicolumn{2}{|c|}{2017} \\
\hline & & & Amount & $\begin{array}{c}\text { Share } \\
(\%)\end{array}$ & amount & $\begin{array}{c}\text { Share } \\
(\%)\end{array}$ \\
\hline \multirow[t]{12}{*}{1.} & BUSINESS & (Unit) & $61,656,547$ & & $62,928,077$ & \\
\hline & UNIT $(\mathrm{A}+\mathrm{B})$ & & & & & \\
\hline & A. Micro, Small, & (Unit) & $61,651,177$ & 99.9 & $62,922,617$ & 99.9 \\
\hline & (SMEs) & & & & & \\
\hline & - Micro & (Unit) & $60,863,578$ & 98.71 & 62.1069 & 98.70 \\
\hline & business & & & & million & \\
\hline & - Small & (Unit) & 731047 & 1.19 & 757090 & 1.20 \\
\hline & business & & & & & \\
\hline & - Enterprises & (Unit) & 56551 & 0.09 & 58627 & 0.09 \\
\hline & Medium & & & & & \\
\hline & Large & (Unit) & 5.370 & 0.01 & 5,460 & 0.01 \\
\hline & Business (UB) & & & & & \\
\hline
\end{tabular}

Source: www.depkop.go.id/data-umkm

To find out taxpayer compliance can be seen from the attitude of taxpayers towards tax and environmental factors. Other factors can also support and be a barrier to making tax payments.
Reviews these inhibiting factors can be investigated by using theory of planned behavioural. 
In this study, researchers will use the Theory of Planned Behavioural (TPB). TPB is a theory used to measure behavioural attention as a predictor of behavioural that describes the relationship between beliefs, attitudes, behavioural, and perceived behavioural control.

Formulation of the problem: (a) Does attitude affects tax compliance? (b) Subjective norms affect tax compliance? (c) Does the perception of behavioural control affect tax compliance?

Based on the problem formulation stated above, the objectives of this study are as follows (a) to analyse and obtain empirical evidence of attitudes towards Taxpayers' compliance with Taxpayers paying; (b) to analyse and obtain empirical evidence of Subjective norms of tax compliance; (c) to analyse and obtain evidence of perceptions of behavioural control over tax compliance?

This research is expected to be able to add insight and knowledge about planned behavioural in SME's Taxpayers behaviour.

\section{Theory of Planned Behaviour (TPB)}

This theory is an extension of the main theory in the field of attitude and behaviour beliefs. Theory of Planned Behavioural aims to show the relationship of behavioural that are raised by individuals to achieve something with control variables. Behavioural control variables mean that not all actions taken by individuals are under the control of reviews these individuals. The following models are presented in the Theory of Planned Behavioural items, namely [1]

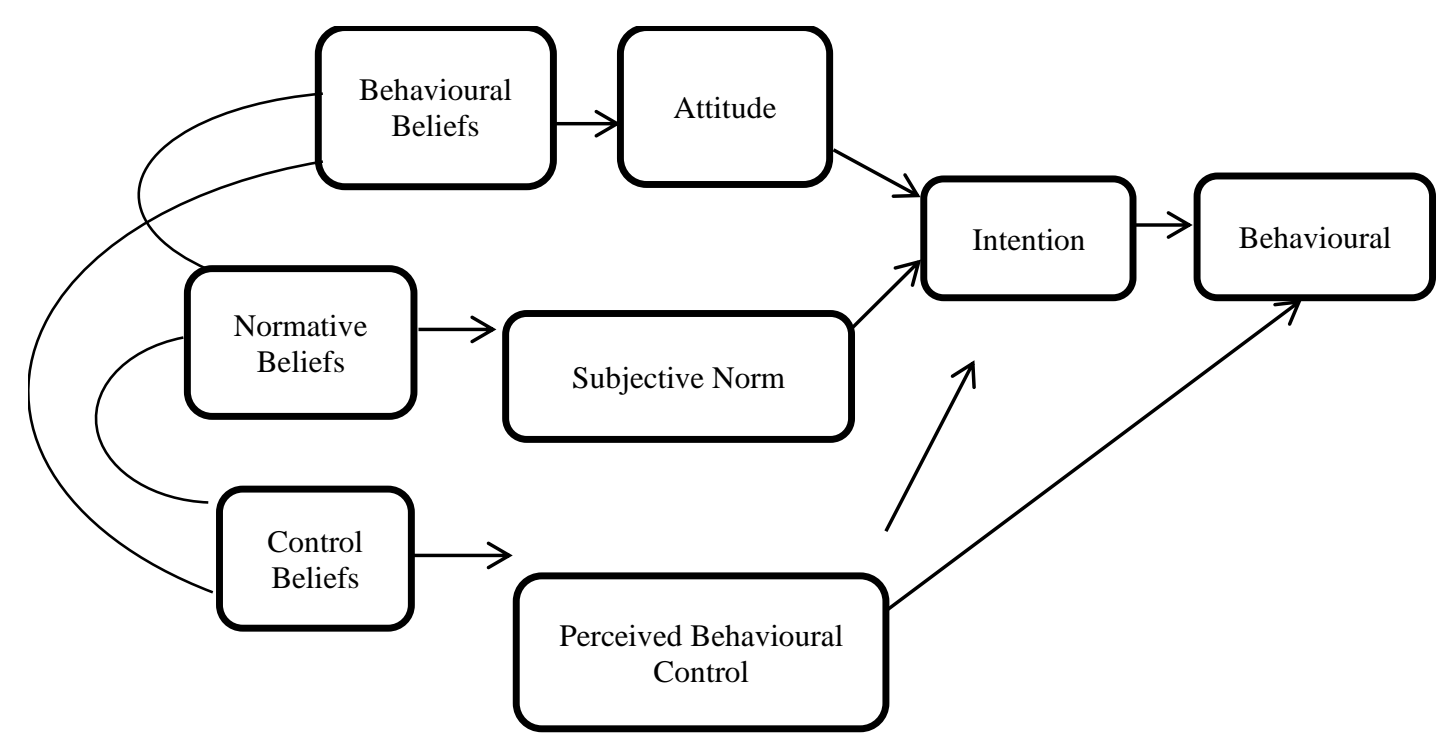

Fig.1. Theory of Planned Behavioural Model

a. Attitude in the Theory of Reasoned Action (TRA) is called attitude towards behavioural. Attitude towards a behavioural is defined as the degree of positive or negative assessment of a behavioural.

b. Subjective Norm (individually subjective) perception individual is defined as the perception of individuals whose social pressure to do or not do a behavioural.

c. Perceived Behavioural Control In general, the more individuals feel many supporting factors and less inhibiting factors to be Able to perform a behavioural, and then the individual will tend range to perceive themselves as easy to perform the behavioural.

\section{Definition of Tax}

Some economists express Reviews their opinions about the notion of tax, Including:

a. [2]"Tax is an achievement that is imposed unilaterally and is owed to the authorities 
(According to the norms set in general), without any contra-achievement, and solely used to cover general expenses".

b. [3]"Tax is an achievement to the government through general norms and the which can be imposed without any performance shown in terms of individuals intended to finance government spending."

c. [4]"Taxes are dues to the state (can be forced) that are owed by Reviews those who pay Them According to regulations, with no achievement back, the which can directly be demonstrated and used is to finance expenses - general expenditure relates to the task of the state the which administers the government. "

d. [5]"Tax as an obligation to hand over part of the wealth to the state treasury they caused by a situation, eventand act that Gives A Certain position, but not as a penalty, According to regulations set by the government and can be forced, but there is no reciprocal service from the state directly, to preserve the state in general".

Tax Function: Budgetary Function and Regular Function. Tax Collection Principle. [6] There are three principles used in tax collection: (a) The Basis of Domicile. (b) Source Basics. (c) National Basics. Collection System: Official Assessment System, Self-Assessment System, Withholding System. Taxpayers [7] Concerning General Provisions and Procedures for Taxation are persons or entities, Including Taxpayers, tax cutters, tax collectors who have taxation rights and obligations in accordance with the provisions of tax legislation.

\section{Definition of Small, Micro and Medium Enterprises}

[8]Micro, Small and Medium Enterprises means:

a. Micro Business is a productive business owned by individuals and / or an individual business entity that meets the criteria for Micro Business as stipulated in this Law.

b. Small Business is a productive economic business that stands alone, the which is
Carried out by individuals or business entities that are not subsidiaries or branch companies that are owned, controlled, or Become a part either directly or indirectly of Medium Enterprises or Large Enterprises that meet the criteria of the Small Business as regulated in this law.

c. Medium Business is a productive economic business that stands alone, the which is Carried out by individuals or business entities that are not subsidiaries or branch companies that are owned, controlled, or Become a part either directly or indirectly with a small business or large business with a net worth or annual sales results as Provided for in this law.

[8] Micro, Small and Medium Enterprises (SME's) are based on:Kinship, Economic democracy, Togetherness, Efficiency with justice, Sustainable, Environmentally friendly, Independence, Balance of progress, National economic unity.

[8]Criteria for Small, Micro and Medium Enterprises: (a) Criteria for Micro Business, (b) Small Business Criteria, (c) Medium Business Criteria.

Principle of Empowerment of Small, Micro and Medium Enterprises

a. Principle of Empowerment of Micro, Small and Medium Enterprises

b. The Purpose of Empowerment of Micro, Small and Medium Enterprises

Implementation of Small, Micro and Medium Enterprises. Government Regulation Number 17 of 2013 concerning the implementation of Law Number 20 of 2008 concerning Micro, Small and Medium Enterprises.

[9] The government had issued a regulation regarding the imposition of final income tax., Regulates the imposition of final income tax and the determination of tax rates on income from businesses received or Obtained by Taxpayers who have gross Certain circulation. This Government Regulation, which was put into effect effectively starting July 1, 2018, is a form of 
convenience for SMEs who have so far experienced difficulty in calculating the amount of tax payable.

[10]Tax compliance can be interpreted as a condition where the taxpayer fulfil all tax obligations in accordance with applicable taxation provisions without any examination, investigation, warning, and application of taxation sanctions both administrative and criminal sanctions.

\section{Qualitative Data Analysis}

[11]Data analysis is a rule of research that must be done by all researchers, because a study without analysis will only give birth to a raw of data that has no meaning. With analysis, the data can be processed and can be concluded, the which in the end, that conclusion is the Forerunner of new knowledge which is the development of previous sciences. Qualitative analysis of data is an attempt to uncover the meaning of the research of data by collecting the data in accordance with certain classifications.

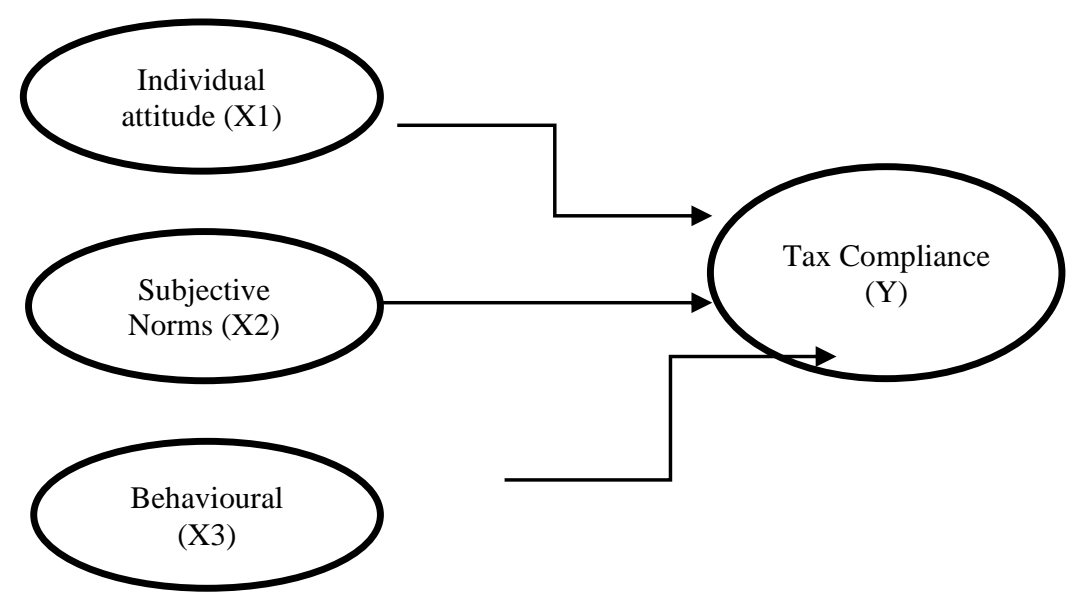

Fig. 2. Analysis Framework

\section{Research Methodology}

The source of data in this study is the 16.534 SME'S taxpayer who is registered at the Department of Cooperatives and SMEs, Depok City, West Java. This research uses the data of primary and secondary data.Data collection in this study was Carried out with documentation and field research (field research), and library research (Library Research). The population in this study were SMEs Taxpayers registered at the Depok City Cooperative andSMEs Service and the sample was the MSME Taxpayer registered at the Depok City Cooperative and SMEs Service using Probability Sampling techniques. To determine the sample size, this study uses the Slovin formula.MSE's at the Department of Cooperatives and MSMEs in Depok City have a TIN.The analysis in this research is to use qualitative analysis of data.

\section{Result and Discussion}

The research was done by spreading the questionnaire to the respondent i.e. taxpayer actors for Micro, Small and Medium registered in the Department of Cooperatives and SMEs by providing direct taxpayer Depok questionnaires directly to SMEs in the area of Depok. The Researchers spread the questionnaire as many as 100 questionnaires to the rate of return of $100 \%$, from 100 questionnaires as much as 5\% broken then the total questionnaires that can be tested items, namely 95 questionnaires.

\section{Descriptive statistics}

[12]Descriptive statistics in the study was primarily aimed to describe or illustrate the 
research object through a sample data or population. Descriptive statistics provide a picture or a description of the data seen from the average (mean), standard deviation, and variance, maximum and minimum.

a. Variable Attitude (X1) has a number of the data $(\mathrm{N})$ of 95 respondents, Showed the Lowest value (minimum) at 7 and highest value (maximum) of 35 , the value (sum) of 2641 and an average value of 27.80. Whereas the standard deviation for the attitude of 4648.

b. Subjective Norms variable (X2) has a number of the data $(\mathrm{N})$ of 95 respondents, Showed the Lowest value (minimum) of 19 and the highest value (maximum) of 35 , the value (sum) of 2389. Whereas the standard deviation for the subjective norm of 2,428.

c. Variable Control Behavioural (X3) has a number of the data (n) of 95 respondents, Showed the Lowest value (minimum) of 14 and the highest value (maximum) of 30 , the value (sum) of 2186. Whereas the standard deviation to control the behavioural of 2,668.

d. Taxpayer Compliance variable (Y) has a number of the data (n) of 95 respondents, Showed the Lowest value (minimum) of 9 and highest value (maximum) of 34 , the value (sum) of 2473 and an average value of 26.03. While the standard deviation for Taxpayer Compliance by 3607 .

\section{Validity test results}

[13]Validity test used to measure whether a legitimate or valid questionnaires. A questionnaireconsidered valid if the questions in the questionnaire were Able to reveal something that will be measured by the questionnaire.Technique used is the Pearson Correlation technique is a way to correlate the score of each item with the total score.

The following are the criteria for testing the validity if $r$ count $>$ ttable then the statement item Valid. Whereas if table then the statement grain
Invalid. Here is a table of the results of the reliability test by using SPSS version 25[14]

1) Attitude (X1). The Indicators or items that measure variables statement Attitude (X1) is invalid becausethe value ofCorrected ItemTotal Correlation greater than $\mathrm{T}$ table.

2) Subjective Norms (X2). The Indicators or statement items of subjective norm variables are valid for all representationsof the variables have the attitudeCorrected ItemTotal Correlation greater than $\mathrm{T}$ table.

3) Behavioural Control (X3). The indicators or statement items of behavioral control variable is valid for all the claims of behavioral control variables haveCorrected Item-Total Correlation ( $\mathrm{r}$ count) greater than $\mathrm{T}$ table.

4) Taxpayer Compliance. The indicators or statement items of a variable tax compliance is valid for all representations of the variablescompliance taxpayerCorrected ItemTotal Correlation ( $\mathrm{r}$ count) greater than $\mathrm{T}$ table.

\section{Reliability test results}

Reliability is a tool to measure a questionnaire which is an indicator of variables or constructs. A questionnaire is said to be reliable or reliable if someone answers on the statement is consistent or stable over time. The reliability of measurement can be done in two ways items, namely:

1) Repeated measure or re-measurement: here a person will be given the same questions at different times, and then see whether it is consistent with the answer.

2) One shot or measurement once: here the measurement only once and then the results were compared with other questions or measure the correlation between the answers to the questions. SPSS Provides facilities measure of reliability with Cronbach Alpha statistical test (a). [14]A construct or a variable is said to be reliable if the value of Cronbach Alpha> 0.70.The variables of attitude (X1) is reliable becauseCronbach's 
Alpha value generated $0,900>0,70$. The variables of Subjective Norms (X2) are reliable, because Cronbach's Alpha value generated 0734> 0.70.The variables of the Control Behavioral (X3) is reliable, because Cronbach's Alpha value generated 0.805> 0.70 .The variables of Taxpayer Compliance (Y) is reliable, because Cronbach's Alpha value generated $0808>0.70$.

\section{Classical Assumption Test Results}

[14] Normality test aims to test whether the regression models or residual confounding variables have a normal distribution. In this research tool used to test for normality by using the Normal Probability Plot (P-Plot). Normality can be detected by looking at the spread of the Data (points) on the diagonal axis of the graph. The results of the normality test of data processing with SPSS version 25 is as follows: Normal P-Plot Graphs dots spread around the diagonal line and follow the direction of the diagonal line. This shows that the regression models in this study meet the assumption of normality.

[14]Multicollinearity test aims to test whether the regression models found a correlation between independent variables (independent) to detect the Multicollinearity can be seen from the value of tolerance or variance value inflation Factor (VIF). If the tolerance value> 0:10 then it means not happen Multicollinearity. Conversely, when the value of tolerance is $<12: 10$ then it means thereMulticollinearity. While the decision if viewed from the VIF is that if VIF $<10$ then it means not happen Multicollinearity. Conversely, when the value of VIF> 10 then it means thereMulticollinearity. The attitude variable (X1) has a tolerance value of 0855 and the VIF at 1,169. Variable subjective norm (X2) have tolerance values of 0.930 and 1.075 VIF. Behavioral control variable (X3) has a tolerance value of 0852 to 1174 amounted to VIF. The test results Showed that the attitude variable (X1), Subjective norms (X2), and control the behavioral (X3) has a value of 0,100 and VIF tolerance $\geq \leq$
10:00 it can be concluded that it did not happen Multicollinearity.

Heteroscedasticity test aims to test whether the regression model of inequality occurred residual variance from one observation to another observation. If the variance of the residuals of the observations to other observations that Werner, it is called and if different homoscedasticity called heteroscedasticity.Detection of the presence or absence of heteroscedasticity can be seen with the presence or absence of a specific pattern on a scatterplot graph. If there are certain patterns indicate that there has been a heteroscedasticity. But if there is no clear pattern as well as the points spread above and below the number 0 on the $\mathrm{Y}$ axis, then there is no heteroscedasticity [14].The spread of the points are above, below and around the numbers 0 , it can be concluded regression models in this study that did not happen Heteroscedasticity.

[14]Autocorrelation test aims to test whether the linear regression models was not correlation between errors nuisance (disturbance term-ed.) In period $t$ and fault bullies in the previous period ( $t$ 1). Autocorrelation test can be done with the Durbin-Watson. The decision Whether or not the autocorrelation is:

1) If $\mathrm{DU}<\mathrm{DW}<(4-\mathrm{Du})$, then there is no autocorrelation

2) If $\mathrm{DW}<\mathrm{dL}$, then there is positive autocorrelation

3) If $D W>(4-d L)$, then there is negative autocorrelation

4) If (4-dU) $<\mathrm{DW}<(4-\mathrm{dL})$, then it cannot be concluded

A value of the Durbin-Watson is 1,918 with a significant level of 0:05 and the amount of the data (n) as many as 95 and $\mathrm{K}$ is worth 3 , the Obtained value of DU at 1.7316 then Obtained value is between 1,918 DW UU of 1.7316 and (4$\mathrm{dU})$ of (4-1.7316) 2,264 results are Obtained. So in this case can be concluded that the regression models in this study did not happen autocorrelation. 
Test Results of Multiple Linear Regression Analysis

Multiple linear regression analysis is a linear relationship between two or more independent variables $(\mathrm{X} 1, \mathrm{X} 2, \mathrm{X} 3 \ldots \mathrm{Xn})$ with the dependent variable $(\mathrm{Y})$. This analysis is to determine the direction of the relationship between independent variables and the dependent from, whether each independent variable associated positive or negative, and to predict the value of the dependent variable when the independent variable value increased or decreased (14). In accordance with the hypothesis being tested inthis study, the multiple linear regression equation is:

$$
\begin{array}{cl}
\mathbf{Y}=\boldsymbol{\alpha}+\boldsymbol{\beta 1 X 1} 1 & +\boldsymbol{\beta 2} \mathbf{X} \mathbf{2}+\boldsymbol{\beta 3 X} \mathbf{3}+\mathbf{e} \\
\text { Information: } & \\
\mathrm{Y} & =\text { Taxpayer Compliance } \\
\mathrm{A} & =\text { constant } \\
\beta_{1} & =\text { Coefficient of regression } \\
\mathrm{X} 1 & =\text { attitude } \\
\beta_{2} & =\text { Coefficient of regression } \\
\mathrm{X} 2 & =\text { Subjective norm } \\
\beta_{3} & =\text { Coefficient of regression } \\
\mathrm{X} 3 & =\text { Control Behavioural } \\
e & =\text { error } / \text { term disruption }
\end{array}
$$

From the data processing the following equation:

$$
\mathrm{Y}=16,534+0,317+0,385 \text { X2 X3 X1-0,326 }
$$

Specification for multiple linear regression results above are:

1) Constant value $(\alpha)$ of 16534 , meaning that if the attitude variable (X1), Subjective norms (X2) and Control Behavioural (X3) has a value of zero (0), then the amount of tax compliance (Y) is equal to 16234 .

2) Attitude variable coefficient value (X1) of 0.317 , meaning that if the attitude variables move up one unit of account become to 0.317 on condition that other constant numbers. With the positive coefficient values attitudinal variables (X1) has a direct relationship with tax compliance $(\mathrm{Y})$, the better the attitude of the taxpayer the better the compliance of the taxpayer in carrying out tax payments.

3) Subjective norm variable coefficient value (X2) is -0326 , meaning that if the variable subjective norm up one unit of account would lead to a reduction of taxpayer compliance by 0326 assuming other variables constant. With a negative coefficient value it means that the subjective norm variables have a relationship that is not the direction or inversely the more the level of subjective norm then the less tax compliance, Because Taxpayers pay taxes to itself is not due to the influence of others.

4) Coefficient of behavioural control variable (X3) of 0.385 , meaning that if variable ride controlbehavioural of the unit of account then amounted to 0.385 Werner assuming other variables constant. With a positive coefficient indicates that the variable control of the conduct has a direct relationship with tax compliance, if good behavioural control the better the compliance of the taxpayer in carrying out tax payments.

\section{Hypothesis testing \\ Coefficient Determination $\mathbf{R}^{2}$}

The coefficient of determination is Analysed to measure how far the model's ability to explain variations in the dependent variable. The coefficient of determination between zero and one, the coefficient of determination small (close to zero) means the ability of independent variables in explaining the variation is very limited dependent variables. While the coefficient of determination is low (close to unity) means independent variables provide almost all the information needed to predict the variation of the dependent variable [14]. The results of the data processing coefficient determination test using SPSS version 25 is as follows:

Table 3. Coefficient Determination Test Results

Model Summary 


\begin{tabular}{l|c|c|c|c|c}
\hline Model & $\mathrm{R}$ & $\begin{array}{c}\mathrm{R} \\
\text { Square }\end{array}$ & $\begin{array}{c}\text { Adjusted R } \\
\text { Square }\end{array}$ & $\begin{array}{c}\text { Std. Error of the } \\
\text { Estimate }\end{array}$ & Durbin-Watson \\
\hline 1 &, $559 \mathrm{a}$ &, 313 &, 290 & 3,039 & 1,918 \\
\hline
\end{tabular}

a. Predictors: (Constant), behaviour control, subjective norms, attitude

b. Dependent Variable: compliance office tax

Source: SPSS output the data are processed writer

From 4:19 table shows that the value of $\mathrm{R}$ Square Obtained amounted to 0,313 , or $31.3 \%$, which indicates that the taxpayer pays tax compliance is influenced by attitudes, Subjective norms and behavioural control.

\section{Feasibility Model (Test F)}

$F$ test done to PROVE whether the independent variables simultaneously have an influence on the dependent variable. F test was conducted to test all of the independent variables on the dependent variable freely concluded a significant 0:05 [14].

If significant value> 0.05 then $\mathrm{HO} \mathrm{Ha}$ accepted and rejected, this means that all the dependent variable of smoking or jointly have influence on the dependent variable, or tied. Meanwhile, if the significant value> 0.05 then $\mathrm{H} 0$ is rejected and $\mathrm{Ha}$ accepted, this means that all the independent variables together or free no influence on the dependent variable, or tied. The results of $\mathrm{F}$ test of data processing with SPSS version 25 is as follows:

Table 4. F Test Results

ANOVA

\begin{tabular}{llccccc}
\hline Model & & Sum of Squares & df & mean Square & F & Sig. \\
\hline 1 & Regression & 382717 & 3 & 127572 & 13817 &, $000 \mathrm{~b}$ \\
& & 840188 & 91 & 9233 & & \\
& residual & 1222.905 & 94 & & & \\
& Total & & & & \\
\hline
\end{tabular}

a. Dependent Variable:compliance office taxcompliance office tax

b. Predictors: (Constant), behaviour control, subjective norms, attitude

Source: SPSS output the data are processed writer

From Table 4:20 shows that $\mathrm{F}$ count greater than $\mathrm{F}$ table that is equal to 13 817> 2.70 with a significant level of 0:00. Due to the significant level of less than 0:05, it can be concluded $\mathrm{HO}$ is rejected and $\mathrm{Ha}$ accepted, so it can be said that the attitudes, norms subject, and control behavioural simultaneously or simultaneously Affect the compliance of SMEs pay taxes.

\section{T Test Results}

[14]t-test was used to test whether each of the independent variables influence the dependent variable significantly. Test this hypothesis by comparing the value of $\mathrm{t}$ arithmetic with $\mathrm{t}$ table Obtained by the significant level of $5 \%$ or $0: 05$. Basis for a decision as follows:

1) $\mathrm{H} 1$ accepted if the probability of $>0.05$

2) $\mathrm{H} 2$ acceptable if the probability of $>0.05$

3) $\mathrm{H} 3$ acceptable if the probability of $>0.05$

Table 5. T Test Results

\section{Coefficient}




\begin{tabular}{|c|c|c|c|c|c|}
\hline \multirow[b]{2}{*}{ Model } & \multicolumn{2}{|c|}{ coefficients unstandardized } & \multirow{2}{*}{$\begin{array}{c}\text { standardized } \\
\text { Coefficients } \\
\text { beta }\end{array}$} & \multirow[b]{2}{*}{$\mathrm{T}$} & \multirow[b]{2}{*}{ Sig. } \\
\hline & B & Std. Error & & & \\
\hline 1 (Constant) & 16534 & 3888 & & 4,252 &, 000 \\
\hline Attitude &, 317 &, 073 &, 409 & 4,350 &, 000 \\
\hline Subjective norm &,- 326 &, 134 &,- 219 & -2432 &, 017 \\
\hline Behaviour control &, 385 &, 127 &, 285 & 3,028 &, 003 \\
\hline
\end{tabular}

a. Dependent Variable: compliance office tax

Source: SPSS output the data are processed writer

\section{Hypothesis 1}

H1: there are significant positive and significant correlations between attitude towards compliance taxpayer pay for SMEs.

The results of hypothesis testing based on calculations SPSS attitudinal variables, $t$ for the regression coefficient is 4.350 t table value X1 (N3 ) to the level of 0:05 with $\mathrm{df}=95$ was 1,986 with a significance level of $0: 00<\alpha=5 \%$ or $0: 05$. Based on the results of the comparison between tcount with t Table $<\alpha=5 \%$ or $0: 05$. Based on the results of the comparison between the $t$ Table namely 4,350 t> 1986 and a ratio of 0:00 significance level of $<0.05$, it can be concluded that $\mathrm{H} 1$ is accepted. This shows that the attitude variable (X1) and a significant positive impact on tax compliance. The results of this study are consistent with empirical studies conducted by [7] and [8] found that attitudes have the significant influence on tax compliance.

\section{Hypothesis 2}

$\mathrm{H} 2$ : There is a negative and significant effect between Subjective norms and adherence to pay taxes SMEs

Results of testing the hypothesis subjective norm variable (X2) based on the calculation of SPSS, $\mathrm{t}$ for the regression coefficient is $-2432 \mathrm{t}$ table value $\mathrm{X} 2(\mathrm{~N}-3)$ to the level of 0:05 with $\mathrm{df}=$ 95 was 1,986 with a significance level of $0.017<\alpha$
$=5 \%$ or 0:05. Based on the results of the comparison between tcount with t table $<\alpha=5 \%$ or 0:05. Based on the results of the comparison between tcount with $\mathrm{t}$ Table is $-2432<1,986$ and 0.017 significance level ratio of $<0.05$, it can be concluded $\mathrm{H} 2$ received. This shows that the subjective norm has significant negative effect on tax compliance. This is in line with the previous empirical studies [7] shows which the subjective norm has a significant effect on the compliance of paying taxes.

\section{Hypothesis 3}

H3: There is a positive influence and significant between control behavioural towards SMEs pay tax compliance

The results of hypothesis testing behavioural control variable (X3) based on the calculation of SPSS, $t$ for the regression coefficient is $3,028 \mathrm{t}$ Table value X3 (N-3) to the level of 0:05 with $\mathrm{df}$ $=95$ was 1,986 with a significance level of 0:03 $<\alpha=5 \%$ or $0: 05$. Based on the results of the comparison between tcount with t Table $<\alpha=5 \%$ or 0:05. Based on the results of the comparison between tcount with $t$ Table namely 3,028> 1,986 and a ratio of 0:00 significance level of $<0.05$, it can be concluded H3 is received. This shows that behavioural control variable $\mathrm{X} 3$ is positive and significant effect on adherence pay taxes. The results of this study are consistent with empirical 
studies conducted [14] and [12] found that attitudes have the significant influence on tax compliance.

\section{Summary of Results}

In this study, the object of his research is the analysis of compliance of paying taxes in terms of planned behavioural theory to Taxpayers SME's Studies in the Department of Cooperatives and SME's Depok City roommates is located Dibaleka VII Building II Floor Jl. Margonda Raya No. 54 Depok Subdistrict. Pancoran Mas, Depok, West Java. The sampling technique using the formula Slovin with a population of 1,650 SME's, the samples Obtained from the calculation of the formula is 95 respondents SMEs registered in the Department of Cooperatives and SME's Depok city.

Based on the classic assumption test that has been done is Obtained with the following caption:

a. Test normality of Normal P-plot graph dots spread around the diagonal line and follow the direction of the diagonal line. This shows that the regression models in this study meet the assumption of normality.

b. Multicollinearity test results show the value of tolerance for the independent variable attitudes (X1) of 0855, subjective norm (X2) of 0930 and 0852 for behavioural control all values greater than 0:10 Tolerance means not happen multicollinearity. While the value of VIF weeks to attitudinal variables (X1) of 1,169 , subjective norm (X2) of 1,075 and behaviour control (X3) of 1174 less than 10 . It can be concluded in this study did not happenmulticollinearity.

c. The test resultheteroscedasticity. result the distribution of dots crowd who Gathered and Stood at 0 , it can be concluded regression models in this study that there Heteroscedasticity.

d. Autocorrelation test results reveals that a value of the Durbin-Watson is 1,918 with a significant level of 0:05 and the amount of the data (n) as many as 95 and $\mathrm{K}$ is worth 3 , the
Obtained value of $\mathrm{dU}$ at 1.7316 then Obtained value is between $1,918 \mathrm{DW}$ dU at 1.7316 and (4-dU) of (4-1.7316) 2,264 results are Obtained. So in this case can be concluded that the regression models in this study did not happen autocorrelation.

e. Multiple regression analysis of the following is the result of multiple linear regression:

1) Constant value $(\alpha)$ of 16534 , meaning that if the attitude variable (X1), Subjective norms (X2) and Control Behavioural (X3) is considered changed (constant) then the value of the dependent variable Individual Taxpayer Compliance (Y) continues to run well.

2) Attitude variable coefficient value (X1) of 0.317 , meaning that if the attitude variables move up one unit of account become amounted to 0.317 on condition that other constant numbers. With the positive coefficient values attitudinal variables (X1) has a direct relationship with tax compliance $(\mathrm{Y})$, the better the attitude of the taxpayer the better the compliance of the taxpayer in carrying out tax payments.

3) Subjective norm variable coefficient value (X2) is -0326 , meaning that if the variable subjective norm up one unit of account then Decreased by 0326 assuming other variables constant. With a negative coefficient value it means that the subjective norm variable trade-offs have Increasingly more and more levels of subjective norm then the less tax compliance, Because Taxpayers pay taxes to consciousness itself is not the influence of the environment.

4) Coefficient of behavioural control variable (X3) of 0.385 , meaning that if variable ride controlbehavioural of the unit of account become to 0.385 Werner assuming other variables constant. With a positive coefficient indicates that the variable control of the conduct has a 
direct relationship with tax compliance, if good behavioural control the better the compliance of the taxpayer in carrying out tax payments.

f. Coefficient of determination(R2) shows that the value of $\mathrm{R}$ Square Obtained amounted to 0,313 , or $31.3 \%$, which indicates that the taxpayer pays tax compliance was effected by attitudes, Subjective norms and behavioural control.

g. Test $\mathrm{f}$ shows that $\mathrm{F}$ count greater than $\mathrm{F}$ table that is equal to $13817>2.70$ with a significant level of 0:00. Due to the significant level of less than 0:05, it can be concluded $\mathrm{HO}$ is rejected and $\mathrm{Ha}$ accepted, so it can be said that the attitudes, norms subject, and control behavioural simultaneously or simultaneously Affect the compliance of SMEs pay taxes.

h. T-test, the which is done through Several stages of testing, the results can be explained as follows:
1) Variable attitude positive and significant impact on the compliance of SMEs pay taxes, this can be seen from the table namely 4,350 t> 1986 and a ratio of 0:00 significance level of $<0.05$.

2) Subjective norm variable has a negative and significant impact on the compliance of SMEs pay taxes, amounting to negative $t$ count because -2432 this can be seen by the results of the comparison between tcount with $t$ table namely 2,432> 1,986 and 0.017 significance level ratio of $<0.05$.

3) Behavioural control variables have a significant and positive effect on compliance SMEs pay taxes, this can be seen by the results of the comparison between $\mathrm{t}$ count with $\mathrm{t}$ table namely $3,028>1,986$ and a ratio of 0:00 significance level of $<0.05$.

Table 6. Hypothesis Test Results

\begin{tabular}{|c|c|c|c|c|c|}
\hline \multirow[t]{2}{*}{ No. } & \multirow[t]{2}{*}{ hypothesis } & \multicolumn{2}{|c|}{ Description } & \multirow[t]{2}{*}{ Research result } & \multirow[t]{2}{*}{ Conclusion } \\
\hline & & Value & Sig & & \\
\hline 1 & $\begin{array}{l}\text { H1 } \\
\text { Compliance } \\
\text { Affects SMEs } \\
\text { positively attitude } \\
\text { Paying Taxes }\end{array}$ & $\begin{array}{l}\mathrm{t} \text { count }>\mathrm{t} \text { table } \\
\text { of } 4.350>1,986\end{array}$ & $\begin{array}{l}\text { Significance } \\
\text { of } 0.000> \\
0.05 \text {. }\end{array}$ & $\begin{array}{l}\text { attitudes influence } \\
\text { Compliance positive } \\
\text { and significant } \\
\text { impact on SMEs } \\
\text { Paying Taxes }\end{array}$ & $\begin{array}{l}\text { H1 } \\
\text { Accepted }\end{array}$ \\
\hline 2 & $\begin{array}{l}\mathrm{H} 2 \\
\text { Subjective norms } \\
\text { negative effect on } \\
\text { Paying Tax } \\
\text { Compliance SMEs }\end{array}$ & $\begin{array}{l}\mathrm{t} \text { count }>\mathrm{t} \text { table } \\
\text { of }-2432<1,986\end{array}$ & $\begin{array}{l}\text { Significance } \\
\text { of } 0.000 \\
<0.017 \text {. }\end{array}$ & $\begin{array}{l}\text { Subjective norm } \\
\text { significant negative } \\
\text { effect on Paying Tax } \\
\text { Compliance SMEs, } \\
\text { this is Because The } \\
\text { taxpayer pays with } \\
\text { his own } \\
\text { consciousness. }\end{array}$ & $\begin{array}{l}\mathrm{H} 2 \\
\text { Accepted }\end{array}$ \\
\hline 3 & $\begin{array}{l}\mathrm{H} 3 \\
\text { Control } \\
\text { Compliance } \\
\text { Behavioural } \\
\text { positive effect on } \\
\text { SMEs Paying }\end{array}$ & $\begin{array}{l}t \text { count }>t \text { table } \\
\text { of } 3,028>1,986\end{array}$ & $\begin{array}{l}\text { Significance } \\
\text { of } 0.000> \\
0.05 \text {. }\end{array}$ & $\begin{array}{l}\text { Behavioural control } \\
\text { positive and } \\
\text { significant impact } \\
\text { on SMEs Paying } \\
\text { Tax Compliance }\end{array}$ & $\begin{array}{l}\text { H3 } \\
\text { Accepted }\end{array}$ \\
\hline
\end{tabular}


Taxes

\section{Conclusion and Recommendations}

\section{Conclusion}

From the research that has been done against the respondent registered at the Department of Cooperatives and SME's Depok, there were 95 respondents were sampled and based on the data collected and processed using SPSS, this study can be summarized as follows:

1. The first independent variable is the attitude positive and significant effect on adherence pay taxes Micro, Small and Medium Enterprises (SME's). Variable attitude $\mathrm{r}$ count $4,3501,986 \mathrm{t}$ Table ratio greater than 0:00 significance level of less than 0:05. This shows that attitudes have a Considerable influence on the compliance of Taxpayers who pay taxes have a positive attitude tax to the taxpayer will be paying taxes dutifully, but Taxpayers who have a negative attitude towards taxes will tend range to pay taxes dutifully. In the study Showed Taxpayers have a positive attitude toward taxes.

2. The second independent variable that is subjective norm significantly negative effect on adherence pay taxes Micro, Small and Medium Enterprises (SME's). Variable subjective norm $t$ has the 2432 is smaller than the $\mathrm{t}$ table of 1986 with a significance of 0.017 ratio is less than 0:05. No significant influence suggests that many Taxpayers to pay tax on consciousness itself are not on their suggestions or opinions of others.

3. The third variable that controls the behavioural of the positive and significant effect on adherence pay taxes Micro, Small and Medium Enterprises (SME's). Behavioural control variables have the t 3,028 greater than the ttable 1986 with 0.003 significance level of less than 0:05. This shows that the better control the behavioural of the taxpayer owned the better the compliance of paying taxes, the study shows that Taxpayers already have a good control behavioural.

\section{Suggestion}

Once the research has been done and has obtained the above Conclusions, the advice can be given related to this study are as follows:

1. For the Department of Cooperatives and SME's Depok should do to cooperate with the authorities of taxation such as the local Tax Office to disseminate information about the importance of tax that the taxpayer perpetrators of Micro, Small and Medium Enterprises (SME's) have a perception of behavioural better control about the ease and barriers in taxation. So that more and more Taxpayers who have a positive attitude towards the tax, because in this study of three variables attitude, subjective norm, and control the behavioural, attitude variables have the highest impact than others.

2. For Taxpayers perpetrators of Micro, Small and Medium Enterprises (SME's), both with Reviews their subjective norm as suggestions and opinions of others or even better is to self-awareness is expected to further improve compliance in paying taxes in accordance with provisions as a form of contribution to the country.

3. For subsequent Researchers interested in conducting research use Theory of Planned Behavioural taxation or the theory of planned behavioural can change Reviews their place in the town of Depok besides research that taxpayer compliance in other areas that have not been investigated in compliance know how much Taxpayers. 


\section{References}

[1] Ajzen and Fisbbein in 1975, Belief, attitude, intention and behavioural: An introduction to theory and research Publisher: Reading, MA: Addison-Wesley

[2] Mardiasmo.Taxation Revised Edition, 2011.Yogyakarta: Andi. 2011.

[3] Mardiasmo.Taxation Revised Edition, 2011.Yogyakarta: Andi. 2011.

[4] Waluyo. 2013. Taxation Indonesia. Jakarta: Four Salemba

[5] Siahaan, Marihot P. 2010. Local Taxes and Levies. Revised Edition. Jakarta: RajawaliPers.

[6] Abdul Halim and Muhammad Sham Kusufi. 2014. Regional Financial Accounting. Issue 4. Jakarta: Four Salemba.

[7] Halim, Abdul, IcukRanggaBowo and Amin Dara, 2014, "Taxation: Concepts, Applications, Examples and Case Studies", Jakarta: Four Salemba.

[8] Halim, Abdul, IcukRanggaBawono and Amin Dara, 2017, "Taxation: Applications, Examples and Case Studies", 2nd Edition, Jakarta: Four Salemba.

[9] Taxpayers According to Law Number 16 of 2009 Law Number 36 Year 2008 Fourth Amendment of Law Number 7 of 1983 concerning Income TaxAct No. 16 of 2009. About General Provisions and Procedures Pepajakan.

[10] According to Law Number 20 of 2008 concerning Micro, Small and Medium Enterprises,Law Number 36 Year 2008 Fourth Amendment of Law Number 7 of 1983 concerning Income TaxAct No. 16 of 2009. About General Provisions and Procedures Pepajakan.

[11] Government Regulation No. 23 Year 2018 About the income tax on income from business derived by a taxpayer who has a certain Gross Circulation.

[12] Government Regulation No. 23 Year 2013 About Income Tax on Income from
Business Received or obtained Taxpayers Who Have Specific Gross Circulation.

[13] Ghozali, Priest, 2016, "Application Analysis with SPSS 23 Multivariete", Semarang: Diponegoro University Publishers Agency.

[14] Sujarweni,Wiratna, 2015:

29.MetodologiPenelitianBisnis dan EkonomiGhozali, 2016: 52).

[15] Ghozali, Priest, 2016, "Application Analysis with SPSS 23 Multivariete", Semarang: Diponegoro University Publishers Agency. 